\title{
Potential therapeutic uses of intraoral mesenchymal stem cells in other tissues of the body: A review
}

\author{
Valentina Villarroel ${ }^{1}$, Pascale Fagalde ${ }^{1}$, David Reininger ${ }^{2}$ \\ ${ }^{1}$ DDS, Private Practice \\ ${ }^{2} \mathrm{DDS}, \mathrm{PhD}$, Master in Oral Surgery and Implantology, Assistant Professor, Universidad Mayor, Santiago, Chile
}

\author{
Correspondence: \\ Universidad Mayor \\ Avda Liber Bernardo O'Higgins 2013 \\ Santiago, Chile \\ david.reininger@umayor.cl
}

Received: 20/01/2020 Accepted: 10/08/2020

\begin{abstract}
Villarroel V, Fagalde P, Reininger D. Potential therapeutic uses of intraoral mesenchymal stem cells in other tissues of the body: A review. J Clin Exp Dent. 2021;13(3):e259-67.
\end{abstract}

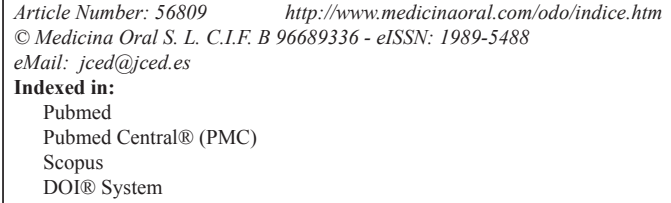

\begin{abstract}
Background: Over the last few years, there has been a great advance in regenerative medicine, with various studies that have observed the ability to repair or regenerate dysfunctional tissues with the patient's own cells, such as with mesenchymal cells. In this area, mesenchymal stem cells (MSCs) from the oral cavity have attracted attention because of their easy access and multiple cellular differentiations. Multiple studies have shown the various clinical applications at the intraoral level, especially at the level of bone regeneration, but the potential applications of oral MSC at a systemic level have been scarcely described. Objective: The objective of this review was to describe the potential therapeutic uses of intraoral MSCs in other tissues of the organism.

Material and Methods: A review of the literature between 2000 and 2019. Only included those studies done on animals or humans.

Results: Twenty five articles were selected, all performed on animals. The donor site most used were the temporary teeth exfoliated from humans, representing $56 \%$ of the total articles, followed by the dental pulp with $28 \%$ of the total articles included. Transplantation of intraoral mesenchymal cells in animals with neural tissue illness was the most studied therapy.

Conclusions: Although obtaining MSC of intraoral origin has proven to be a good alternative in regenerative medicine, achieving therapeutic uses in bone tissue, nervous tissue, liver tissue, skin tissue, ocular tissue, reperfusion of tissues and in autoimmune diseases, there is a lack of clinical studies that allow its safe use in humans.
\end{abstract}

Key words: Mesenchymal stem cells, stem cell transplantation, regenerative medicine, dental component.

\section{Introduction}

Regenerative medicine is a multidisciplinary field that through stem cells, scaffolds and growth factors seeks to repair, regenerate or replace tissues, cells or organs that have been damaged. Stem cells are undifferentiated cells capable of self-renewing to replicate themselves, giving rise to specialized cells under appropriate conditions. There are several types of stem cells, among which we find the mesenchymal stem cells (MSC) (1).

The MSC are multipotential adult cells, which fulfill the function of maintaining and repairing the cell population. The characteristics of the MSC is that they have 
immunomodulatory and immunosuppressive properties altering the innate and adaptive immune response of the individual, in addition, they are able to pass unnoticed in front of the immune system having the potential to be used in therapeutic roles $(1,2)$.

In addition, MSC are able to migrate and graft into damaged tissues where they exert functional and local effects; secrete bioactive molecules such as growth factors, cytokines and chemokines which allow them to have antiapoptotic effects and the stimulation of tissue regeneration (2) and finally, they have plasticity, which is defined as the ability of a cell to differentiate into mature cells different from those of its tissue of origin. This means that they are able to differentiate not only in cells of the mesoderm, but also in cells of the endoderm and ectoderm (1). All these properties of MSC have called attention to use them for therapeutic purposes in tissues or organs damaged in the life of different individuals.

Currently it has been shown that MSC are possible to find in multiple sites of the organism, with MSC coming from the bone marrow the main source of obtaining this type of cells and at the same time they have been the most studied, so they are the apparent gold standard established (2).

However, a medical team is necessary for general or epidural anesthesia to be obtained, where there is also postoperative pain, morbidity risks for the patient and it is considered an invasive procedure when compared to the extraction of stem cells from other parts. of the body. As a result of the disadvantages presented by the bone marrow as a source of MSC, other alternatives of donor sites have been sought, in order to obtain them in a minimally invasive manner (3).

In the oral cavity, unlike other MSC donor sites it is possible to obtain them in a simple and non-invasive way, which are found in the dental pulp (DPSCs), periodontal ligament (PLSCs), apical papilla (SCAP), temporal teeth exfoliated (SHED), dental follicle (DFSCs), periosteum, dental germ (GDSCs), gingival tissue, salivary glands, adipose tissue (ASC) and alveolar bone $(3,4)$.

It has been observed that intraorally these cells have achieved bone regeneration, tooth root regeneration, pulp regeneration, regeneration of the dentin-pulp complex, regeneration of the periodontal ligament and regeneration of periodontal defects $(2,4)$. However, there's still no certainty of the use that has been granted to this type of cells at a systemic level. Therefore, the objective of this research is to describe the potential therapeutic uses of MSCs of intraoral origin in other tissues of the organism.

\section{Material and Methods}

A review of the literature was carried out between 2000 and 2019 in the databases PubMed, EBSCO and Google Scholar, the details of the search methodology can be found in Table 1. Studies animals or in humans were included, studies that used intraoral MSC in damaged tissues outside the stomatognathic system, randomized and non-randomized clinical trials, cohort studies, case-control studies and case reports that were published between the year 2000 to February 2019 in English or Spanish. In vitro and ex vivo studies, narrative reviews, studies that did not specify the MSC used, studies that included animals or humans in pharmacological therapy that affected tissue regeneration, studies that induced immunosuppression or used immunocompromised animals or humans were excluded.

\section{Results}

As a result of the electronic research, a total of 1398 articles were found, of which, by eliminating according to the inclusion and exclusion criteria, a total of 25 articles were selected, as summarized in Figure 1. All articles found in this review belong to studies carried out on animals (Table 2 summarizes the selected articles, 2 cont.). Within the intraoral MSC donor sites used in the selected studies, the most used was SHED in a $56 \%$ of the articles, followed by DPSCs in a $28 \%$ of the studies (Fig. 2).

$68 \%$ of the total articles included in this review indicate the ability of stem cells from the oral cavity to improve multiple tissues or organs damaged by chemical or physical agents such as: improving the structure and function of the liver with liver cirrhosis $(5,6)$, decrease damage on skin exposed to UV-B rays (7), decrease the

Table 1: Search strategy.

\begin{tabular}{|c|c|}
\hline Data Bases & Search Strategies \\
\hline PubMed & $\begin{array}{c}\text { (((“Stem Cells”[Mesh] AND (“Tooth Components”[Mesh] OR "Periodontium”[Mesh] OR "Salivary } \\
\text { Glands” [Mesh]) AND (“Stem Cell Transplantation” [Mesh] OR "Regenerative Medicine”[Mesh])))) } \\
\text { OR ((mesenchymal stromal cells OR Dental stem cells) AND (periodontal ligament OR dental pulp } \\
\text { OR Apical papilla OR dental follicle OR gingival tissue OR alveolar bone OR periosteum OR tooth } \\
\text { germ OR human exfoliated deciduous teeth OR buccal fat pad) AND (autoimmune OR neoplasm OR } \\
\text { viral OR bacterial OR trauma)) }\end{array}$ \\
\hline EBSCO & "Stem cell” AND ("regenerative medicine" OR “Stem Cell Transplantation”) \\
\hline Scholar Google & "Mesenchymal Stem Cells transplantation” AND (Mouth OR Tooth OR Periodontium) \\
\hline
\end{tabular}




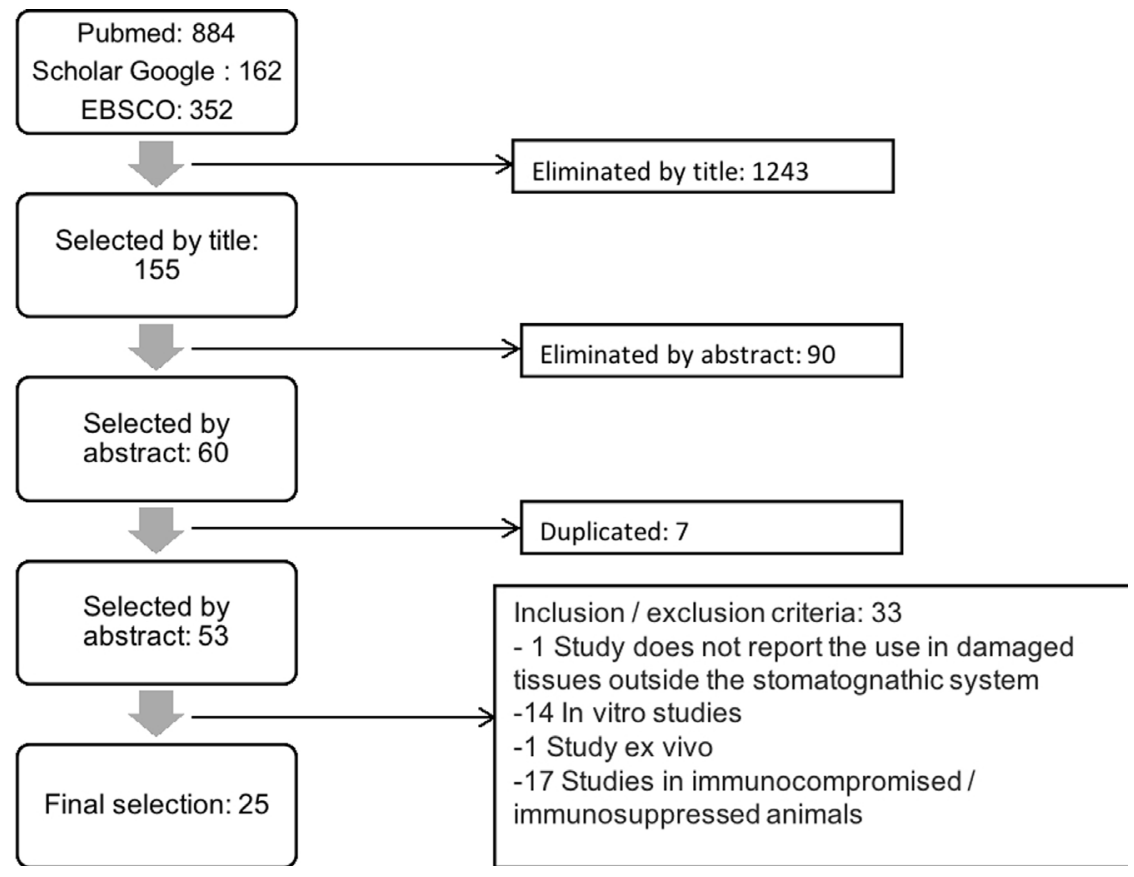

Fig. 1: Articles selection.

damage in organs subjected to heat strokes (8) and cerebral ischemia (9), allow the formation of bone tissue (10-13) and corneal repair (14), improve motor function (15-18) and the muscle action potentials in defective nerve tissue $(19,20)$, increase the regeneration and survival of ganglion retinal cells (21) and reduce apoptosis of neuronal cells (16). $24 \%$ of all articles show therapeutic effects in diseases caused by the immune system, where rheumatoid arthritis is found $(22,23)$, autoimmune encephalomyelitis (24-26), Miastenia Gravis (27) and diabetic polyneuropathy $(28,29)$ (Fig. 3).

\section{Discussion}

According to this review, the most commonly used intraoral MSC donor site is the SHED, being used by $56 \%$ of the total number of studies in this review. $28 \%$ of the articles included, used a conditioned medium from stem cells of exfoliated temporal teeth (SHED-CM). The 7 articles obtained beneficial effects for the corresponding diseases or injuries in which they were conducting their research. Regarding therapeutic uses, the literature also points out the use of MSC of intraoral origin at the level of different tissues:

\section{Bone tissue}

The bone tissue lesions are $16 \%$ of the total of the studies included in this review, of which $75 \%$ performed the transplant of DPSCs and the remaining 25\% performed the transplant with DFSCs. Despite having used different scaffolds the four authors agree in their results in having a greater formation of bone compared to the control group, which presented less or no formation of bone tissue (10-13).

\section{Nervous tissue}

In relation to the therapeutic uses of intraoral MSC, 36\% of the total articles used them as cell therapy in nervous tissue, using 33\% SHED, 33\% SHED-CM and 33\% DPSCs. The studies support the use of this type of cells because they come from the neural crest, due to its ability to express neural markers on its surface, its ability to differentiate into neurons under in vitro conditions and to protect neurons from cellular apoptosis $(8,16,19)$. Feitosa et al. (15) and Nicola et al. $(16,18)$ conducted studies with SHED in animals with spinal cord injury. Both authors report improvements in motor functions after the MSC transplant, where Nicola et al. (16) it is associated with the decrease of apoptosis of neuronal cells and the maintenance of antiapoptotic factors, which would reduce the damage in this type of lesions, thinking that $90 \%$ of the neurons present apoptosis in the first 8 hours after an injury at the level of the spinal cord. In another study of the same author (18) they report that and early transplantation of SHED, in the acute phase of the spinal cord contusion there is an increase of the progenitor cell at 24 hours and reduces the glial scar tissue, so it works as a neuroprotector agent. Asadi-Golsham et al. (17) used intraspinal administration of SHED-CM and they also reported functional recovery in chronic spinal injuries. The authors named above do not achieve regeneration of nervous tissue unlike Sugimura-Wakayama et al. (19) and Mead et al. (21). where the first author reports an increase in myelinated nerve fibers after a lesion in the sciatic nerve in rats using SHED-CM and the second, describes axonal regeneration with an increase in ganglion retinal cells after a lesion occurs in retinal 
Table 2: Summary of the included studies.

\begin{tabular}{|c|c|c|c|c|c|c|}
\hline $\begin{array}{l}\text { Author } \\
\text { (Year) }\end{array}$ & MSC & Trasplant & Via & $\begin{array}{l}\text { Animal/ } \\
\text { Sample }\end{array}$ & Injury or illness & Results \\
\hline $\begin{array}{l}\text { Hirats et al. } \\
(2016)\end{array}$ & SHED-CM & $\mathrm{XG}$ & IP & $\begin{array}{l}\text { Rats } \\
\mathrm{N}: 20\end{array}$ & Hepatic cirrhosis & $\begin{array}{l}\text { Improves the structure of the liver. It decreases significantly: } \\
\text {-The levels of alanine aminotransferase and aspartate aminotransferase in } \\
\text { peripheral blood. } \\
\text {-Expression of proinflammatory genes. } \\
\text { - Increases the polarization of macrophages by expressing MMP13 (hepatic } \\
\text { restorers) }\end{array}$ \\
\hline $\begin{array}{l}\text { Yamaza et al. } \\
(2015)\end{array}$ & SHED & $\mathrm{XG}$ & IP & $\begin{array}{l}\text { Rats } \\
\text { N: } 15\end{array}$ & Hepatic cirrhosis & $\begin{array}{l}\text { - Decreases chronic fibrosis. } \\
\text { - Improves liver functions. } \\
\text { - Suppress the activation of hepatic stellate cells. } \\
\text { - Suppresses Kupffer cells and T cells } \\
\text {-Reduces the expression of proinflammatory interleukins } \\
\text {-Retrieves the decrease of anti-inflammatory interleukins. }\end{array}$ \\
\hline $\begin{array}{l}\text { Ueda and } \\
\text { Nishino }(2010)\end{array}$ & $\begin{array}{l}\text { SHED y } \\
\text { SHED-CM }\end{array}$ & $\mathrm{XG}$ & SC & $\begin{array}{l}\text { Rats } \\
\mathrm{N}: 24\end{array}$ & Skin defect & $\begin{array}{l}\text {-Improvement in fine wrinkles induced by UV-B irradiation. } \\
\text {-Significantly reduce the parameters (number, depth, area) for wrinkles, being } \\
\text { more effective in SHED than in SHED-CM }\end{array}$ \\
\hline $\begin{array}{l}\text { Tseng et al. } \\
(2015)\end{array}$ & SHED & $\mathrm{XG}$ & IV & $\begin{array}{l}\text { Rats } \\
\mathrm{N}: 36\end{array}$ & $\begin{array}{l}\text { Multiple organ } \\
\text { injury due to heat } \\
\text { shock. }\end{array}$ & $\begin{array}{l}\text {-Improves thermoregulatory functional recovery significantly. } \\
\text {-It significantly decreases apoptosis and brain damage. } \\
\text {-They present fewer cellular ischemic markers at brain level. } \\
\text {-Reduces hypoxia and oxidative damage to the hypothalamus. } \\
\text {-Significantly increases the adrenocorticotrophic and corticosterone levels in } \\
\text { the plasma. } \\
\text {-It significantly reduces the apoptosis of the kidney, vessel, lung and liver. } \\
\text {-Significantly decreases the levels of IL-10, TNF- } \alpha \text { and ICAM-1. }\end{array}$ \\
\hline $\begin{array}{l}\text { Zhang et al. } \\
(2018)\end{array}$ & Dental pulp & $\mathrm{AL}$ & IV & $\begin{array}{l}\text { Rats: } \mathrm{N}^{\circ} \\
\text { not } \\
\text { mentioned }\end{array}$ & $\begin{array}{l}\text { Focal cerebral } \\
\text { ischemia }\end{array}$ & $\begin{array}{l}\text { DPSC transplantation combined with brain-derived neurotrophic factor } \\
\text { (BDNF) induced the expression of neural differentiation markers such as } \\
\text { nestin, doublecortin (DCX) and neuronal specific filament (NF-H), suggesting } \\
\text { that BDNF enhances the survival of DPSCs and differentiation into neuronal } \\
\text { cells. DPSCs combined with BDNF enhances neurological recovery after } \\
\text { stroke suggesting a novel therapeutic strategy against cerebral ischemia. }\end{array}$ \\
\hline $\begin{array}{l}\text { Asutay et al. } \\
(2015)\end{array}$ & Dental pulp & $\mathrm{XG}$ & $\mathrm{L}$ & $\begin{array}{l}\text { Rats } \\
\mathrm{N}: 15\end{array}$ & $\begin{array}{l}\text { Bone defects in } \\
\text { the skull }\end{array}$ & $\begin{array}{l}\text { - New area of bone formed } \\
\text { - Greater bone mineral density } \\
\text { - Comparison to the control group. }\end{array}$ \\
\hline $\begin{array}{l}\text { De Mendonça } \\
\text { costa et al. } \\
(2008)\end{array}$ & Dental pulp & $\mathrm{XG}$ & $\mathrm{L}$ & $\begin{array}{l}\text { Rats } \\
\text { N: } 8\end{array}$ & $\begin{array}{l}\text { Bone defects in } \\
\text { the skull }\end{array}$ & $\begin{array}{l}\text { After } 20 \text { days he presented: } \\
\text { - More mature bone } \\
\text { - Formation of lamellae } \\
\text { - Little granulation tissue } \\
\text { In comparison to the group without cell transplantation. } \\
\text { At } 60 \text { days he presented: } \\
\text {-More mature bone } \\
\text {-Denser bone } \\
\text { The group without transplant still had granulation tissue. }\end{array}$ \\
\hline $\begin{array}{l}\text { Petridis et al. } \\
\text { (2015) }\end{array}$ & Dental pulp & $\mathrm{XG}$ & $\mathrm{L}$ & $\begin{array}{c}\text { Rats } \\
\mathrm{N}: 30\end{array}$ & $\begin{array}{l}\text { Bone defects in } \\
\text { the skull }\end{array}$ & $\begin{array}{l}\text { On the eighth week there was greater bone formation significantly compared } \\
\text { to the control group and the group treated only with scaffolding. }\end{array}$ \\
\hline $\begin{array}{l}\text { Rad Rezai et } \\
\text { al. (2015) }\end{array}$ & $\begin{array}{l}\text { Dental } \\
\text { follicle }\end{array}$ & $\mathrm{AG}$ & $\mathrm{L}$ & $\begin{array}{c}\text { Rats } \\
\mathrm{N}: 32\end{array}$ & $\begin{array}{l}\text { Bone defects in } \\
\text { the skull }\end{array}$ & $\begin{array}{l}\text { On the eighth week post treatment: Regeneration and bone healing was } \\
\text { observed significantly. Without being observed in the control group. }\end{array}$ \\
\hline $\begin{array}{l}\text { Feitosa et al. } \\
(2017)\end{array}$ & SHED & $\mathrm{XG}$ & $\mathrm{L}$ & $\begin{array}{l}\text { Dogs } \\
N: 3\end{array}$ & $\begin{array}{l}\text { Chronic spinal } \\
\text { cord injury. }\end{array}$ & $\begin{array}{l}\text { - There is a significant improvement in the function of the extremities } \\
\text { - There were no differences in the data provided by the magnetic resonance so } \\
\text { there is no evidence of regeneration of the spinal cord. }\end{array}$ \\
\hline $\begin{array}{l}\text { Nicola et al. } \\
(2018)\end{array}$ & SHED & $\mathrm{XG}$ & $\mathrm{L}$ & & $\begin{array}{l}\text { Chronic spinal } \\
\text { cord injury. }\end{array}$ & $\begin{array}{l}\text {-SHED transplantation in the acute phase after spinal cord contusion } \\
\text { promoted an increase of progenitor cells as from } 24 \mathrm{~h} \text {. } \\
\text {-Grafted SHED reduced the increase of GFAP expression after } 48 \mathrm{~h} \text {, } \\
\text { promoting an early inhibition of glial scar formation; modulating astrocytic } \\
\text { proteins, such as S100B, delaying the decrease of levels of this protein; and } \\
\text { promoting an increase of Kir4.1, a key protein related to potassium buffering, } \\
\text { essential for reducing neuronal excitability. SHED improved the functional } \\
\text { recovery, they act as a neuroprotector agent after transplantation, probably } \\
\text { through paracrine signaling and tissue plasticity mechanisms. }\end{array}$ \\
\hline $\begin{array}{l}\text { Nicola et al. } \\
(2017)\end{array}$ & SHED & $\mathrm{XG}$ & $\mathrm{L}$ & $\begin{array}{l}\text { Rats: } \mathrm{N}^{\circ} \\
\text { not } \\
\text { mentioned }\end{array}$ & $\begin{array}{l}\text { Chronic spinal } \\
\text { cord injury }\end{array}$ & $\begin{array}{l}\text { - On day } 7 \text { he begins to recover his motor function, staying until the sixth } \\
\text { week. } \\
\text { - Reduction in neuronal tissue loss } \\
\text { - Greater amount of white substance. } \\
\text { - By the sixth week it partially preserves the number of motor neurons } \\
\text { significantly } \\
\text {-It reduces the infiltration of T cells, the levels of TNF- } \alpha \text {, EAAT3, nNOS, the } \\
\text { percentage } \\
\text { of neuronal apoptosis and maintains the levels of BCL-XL (antiapoptotic } \\
\text { factor). }\end{array}$ \\
\hline $\begin{array}{l}\text { Sugimura } \\
\text { Wakayama et } \\
\text { al. }(2015)\end{array}$ & SHED-CM & $\mathrm{XG}$ & IM & $\begin{array}{c}\text { Rats } \\
\mathrm{N}: 30\end{array}$ & $\begin{array}{c}\text { Defective sciatic } \\
\text { nerve }\end{array}$ & $\begin{array}{l}\text { - Increased the number of regenerated and myelinated nerve fibers - Increased } \\
\text { motor function and muscle action potentials. } \\
\text { - The weight of the gastronemius muscle was relatively higher in the } \\
\text { reinnervated muscle. }\end{array}$ \\
\hline
\end{tabular}


Table 2 cont.: Summary of the included studies.

\begin{tabular}{|c|c|c|c|c|c|c|}
\hline $\begin{array}{l}\text { Asadi-Golshan } \\
\text { et al. }(2018)\end{array}$ & SHED-CM & $\mathrm{XG}$ & $\mathrm{L}$ & $\begin{array}{l}\text { Rats: } \mathrm{N}^{\circ} \\
\text { not } \\
\text { mentioned }\end{array}$ & $\begin{array}{l}\text { Chronic spinal } \\
\text { cord injury }\end{array}$ & $\begin{array}{l}\text { Intraspinal administration of SHED-CM with hydrogel: } \\
\text { - Promotes functional recovery in patients with compressive insults of the } \\
\text { spinal cord in comparison to control group. }\end{array}$ \\
\hline $\begin{array}{l}\text { Tsuruta et al. } \\
(2018)\end{array}$ & SHED-CM & $\mathrm{XG}$ & IV & $\begin{array}{l}\text { Rats: } \mathrm{N}^{\circ} \\
\text { not } \\
\text { mentioned }\end{array}$ & $\begin{array}{l}\text { Peripheral nerve } \\
\text { injury en } \\
\text { pacientes con } \\
\text { disfagia }\end{array}$ & $\begin{array}{l}\text { A novel visceral nerve lesion model with dysphagia in the rat was established, } \\
\text { and SHED-CM was found to improve dysphagia in this model ( } 7 \text { days of } \\
\text { observation of the food intake and body weght) SHED-CM protects the } \\
\text { swallowing reflex, reduces pharyngeal residue, promotes axon regeneration } \\
\text { after SLN injury, upregulates trophic factors and promotes vascularization at } \\
\text { the injury site and recruits M2 macrophages at the injury site. }\end{array}$ \\
\hline $\begin{array}{l}\text { Mead et al. } \\
(2013)\end{array}$ & Dental pulp & $\mathrm{AG}$ & $\mathrm{L}$ & $\begin{array}{c}\text { Rats } \\
\text { N: } 18\end{array}$ & $\begin{array}{l}\text { Axotomized } \\
\text { retinal ganglion } \\
\text { cells. }\end{array}$ & $\begin{array}{l}\text { - At } 7 \text { days there was no significant thinning in the thickness of the nerve fiber } \\
\text { layer of the retina. } \\
\text { - At } 14 \text { days there was a significant thinning in the thickness of the nerve fiber } \\
\text { layer of the retina. } \\
\text { - At } 21 \text { days in the group, elevated levels of neurotrophins are observed in the } \\
\text { retina and increases the survival of ganglion retinal cells. } \\
\text { - There was greater axonal regeneration. }\end{array}$ \\
\hline $\begin{array}{l}\text { Gomes et al. } \\
\text { (2010) }\end{array}$ & SHED & $\mathrm{XG}$ & $\mathrm{L}$ & $\begin{array}{l}\text { Rabbit } \\
\mathrm{N}: 15\end{array}$ & Cornea injury & $\begin{array}{l}\text { - Improves corneal transparency } \\
\text { - Shows cleaner corneas } \\
\text { - Presents less neovascularization being more notorious in the group with } \\
\text { medium burns than in the group with severe burns, which presented multiple } \\
\text { layers of corneal epithelium with well differentiated cells. }\end{array}$ \\
\hline $\begin{array}{l}\text { Chen et al. } \\
\text { (2013) }\end{array}$ & $\begin{array}{l}\text { Gingival } \\
\text { Tissue }\end{array}$ & $\mathrm{XG}$ & IV & $\begin{array}{l}\text { Rats: } \\
\mathrm{N}^{\mathrm{o}} \\
\text { not } \\
\text { mentioned }\end{array}$ & $\begin{array}{l}\text { Rheumatoid } \\
\text { arthritis }\end{array}$ & $\begin{array}{l}\text { At } 14 \text { days there was a delay and decrease in the severity of arthritis. } \\
\text { - Significantly reduces synovitis, destruction of bone and cartilage. } \\
\text { - Inhibits the proliferation and differentiation of CD } 4+\text { T lymphocytes by } \\
\text { CD } 73 \text { and CD } 39 \text { signals without the death of the latter. } \\
\text { - Decrease proinflammatory cytokines } \\
\text { - The percentages of Th1 and Th17 cells decrease. } \\
\text { - Significantly increase the frequency of CD } 4+\text { FoxP3 + CD39 cells in the } \\
\text { spleens, lymph nodes and synovial fluid. } \\
\text { - Increase the frequency of induced regulatory T cells but not natural } \\
\text { regulatory T cells }\end{array}$ \\
\hline $\begin{array}{l}\text { Ishika-wa et al. } \\
\text { (2016) }\end{array}$ & SHED-CM & $\mathrm{XG}$ & IV & $\begin{array}{l}\text { Rats } \\
\text { N: } 15\end{array}$ & $\begin{array}{l}\text { Rheumatoid } \\
\text { arthritis }\end{array}$ & $\begin{array}{l}\text {-Clinically present lower foot swelling } \\
\text {-Reduction in synovial inflammation } \\
\text {-Decrease in the destruction of bone and cartilage } \\
\text {-Increase the expression of M2-related anti-inflammatory genes } \\
\text {-It reduces the expression levels of proinflammatory M1 markers. }\end{array}$ \\
\hline $\begin{array}{l}\text { Rossa-to et al. } \\
\text { (2017) }\end{array}$ & SHED & $\mathrm{XG}$ & IP & $\begin{array}{l}\text { Rats } \\
\text { N: } 8\end{array}$ & $\begin{array}{l}\text { Autoimmune } \\
\text { encephalomyelitis } \\
\text { (multiple } \\
\text { sclerosis) }\end{array}$ & $\begin{array}{l}\text { At } 14 \text { days: } \\
\text {-Improved clinical activity } \\
\text {-In the central nervous system reduces the number of IFN- } \gamma+\mathrm{CD} 8+, \mathrm{IL}-4+ \\
\mathrm{CD} 8+, \mathrm{IFN}-\gamma+\mathrm{CD} 4+\text { and IL- } 4+\mathrm{CD} 4+ \\
\text {-Increases the expression of Foxp } 3+\mathrm{CD} 4+\text { in the spleen }\end{array}$ \\
\hline $\begin{array}{l}\text { Shimo-jima et } \\
\text { al. (2015) }\end{array}$ & SHED-CM & $\mathrm{XG}$ & IV & $\begin{array}{l}\text { Rats: } \mathrm{N}^{\circ} \\
\text { not } \\
\text { mentioned }\end{array}$ & $\begin{array}{l}\text { Autoimmune } \\
\text { encephalomyelitis } \\
\text { (multiple } \\
\text { sclerosis) }\end{array}$ & $\begin{array}{l}\text { - Clinical improvement } \\
\text { - Reduces demyelination, axonal injury, infiltration of inflammatory cells and } \\
\text { expression of proinflammatory cytokines. }\end{array}$ \\
\hline $\begin{array}{l}\text { Trubia-ni et al. } \\
\text { (2015) }\end{array}$ & LP & $\mathrm{XG}$ & IV & $\begin{array}{c}\text { Rats } \\
\mathrm{N}: 30\end{array}$ & $\begin{array}{l}\text { Autoimmune } \\
\text { encephalomyelitis } \\
\text { (multiple } \\
\text { sclerosis) }\end{array}$ & $\begin{array}{l}\text { Presents neuroprotective effects } \\
\text {-Improves clinical severity and functional recovery } \\
\text {-Reduces demyelination, axonal loss, infiltration of inflammatory cells } \\
\text {-Modulates the production of CD } 4 \text { T cells and CD } 8 \alpha \text { T cells } \\
\text {-Inhibits the triggering of apoptosis. }\end{array}$ \\
\hline $\begin{array}{l}\text { Ulusoy et al. } \\
\text { (2015) }\end{array}$ & $\begin{array}{l}\text { Dental } \\
\text { follicle }\end{array}$ & $\mathrm{XG}$ & IV & $\begin{array}{l}\text { Rats } \\
\mathrm{N}: 40\end{array}$ & Miastenia gravis & $\begin{array}{l}\text { - There is a significantly lower incidence and severity of the disease. } \\
\text { - Suspension time on the major screen. } \\
\text { - They have significantly lower levels of anti-MuSK IgG, IgG1, IgG2b and } \\
\text { IgG3. } \\
\text {-Significantly lower percentages of } 1 \mathrm{NMJ}, \operatorname{IgG} \text { and C3. } \\
\text {-Significant suppression of CD11b + lymph node cells. } \\
\text {-Suppression of proliferation and production of cytokines (IL-6 and IL-12). }\end{array}$ \\
\hline $\begin{array}{l}\text { Omi et al. } \\
(2017)\end{array}$ & Dental pulp & $\mathrm{AL}$ & IM & $\begin{array}{l}\text { Rats : } \mathrm{N}^{\circ} \\
\text { not } \\
\text { mentioned }\end{array}$ & $\begin{array}{c}\text { Diabetic } \\
\text { polyneuropathy. }\end{array}$ & $\begin{array}{l}48 \text { weeks after the injection of streptozotocin in the rats, intramuscular } \\
\text { injection of DPSCs was performed and significant reductions in the sciatic } \\
\text { motor / sensory nerve conduction velocity, increases in the current perception } \\
\text { threshold, and decreases in capillary density in skeletal muscles and intra - } \\
\text { epidermal nerve fiber compared with normal rats, all of which were } \\
\text { ameliorated by DPSC transplantation. } \\
\text { Sural nerve morphometrical analysis revealed that the transplantation of } \\
\text { DPSCs significantly increased the myelin thickness and area. DPSC- } \\
\text { conditioned media promoted the neurological outgrowth of dorsal root } \\
\text { ganglion neurons and increased the viability and myelin-related protein } \\
\text { expression of Schwann cells. }\end{array}$ \\
\hline $\begin{array}{l}\text { Hata et al. } \\
(2015)\end{array}$ & Dental pulp & $\mathrm{AG}$ & IM & $\begin{array}{l}\text { Rats } \\
\text { N: } 8\end{array}$ & $\begin{array}{c}\text { Diabetic } \\
\text { polyneuropathy. }\end{array}$ & $\begin{array}{l}\text {-Significantly improves the motor and sensitive nerve conduction velocity, the } \\
\text { blood flow in the sciatic nerve. } \\
\text {-Increase the capillaries of the skeletal muscle, Improve sensory damage }\end{array}$ \\
\hline
\end{tabular}




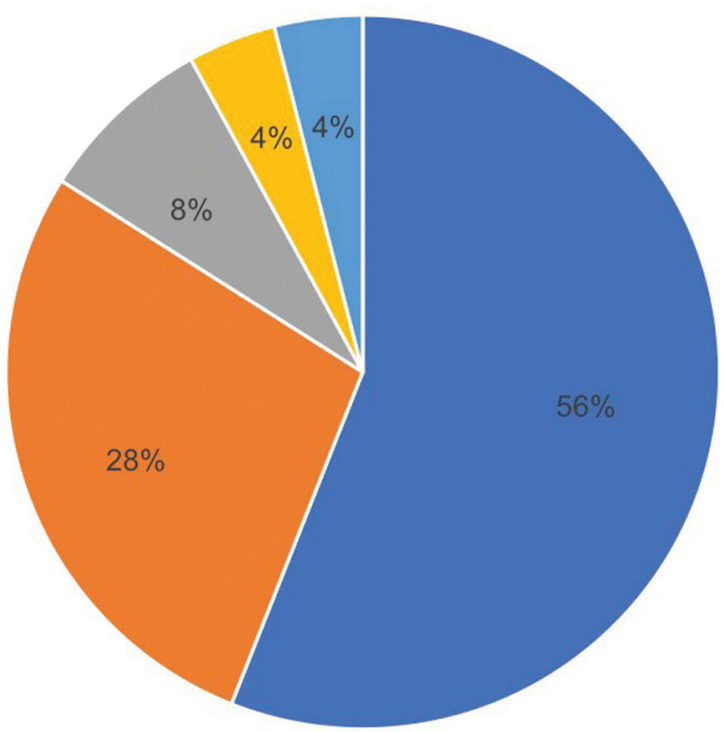

-SHED $=$ Dental Pulp $=$ Dental Follicle $=$ Gingival Tissue $=$ Periodontal Ligament Fig. 2: Intraoral donor sites of MSC.

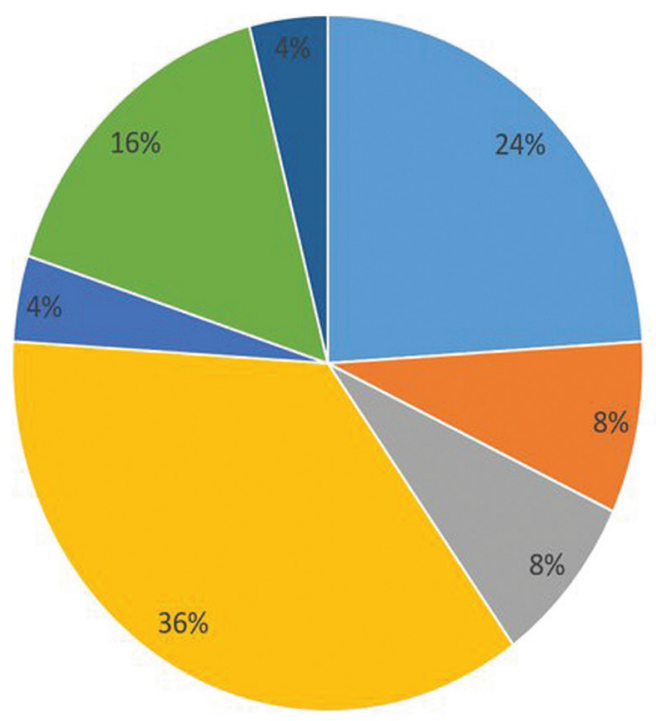

- Autoimmune Diseases Hepatic Tissue

- Skin Tissue

Fig. 3: Uses of intraoral MSC.
- Reperfusion
Neural Tissue
- Corneal Tissue

ganglion cells using DPSC. Tsuruta et al. (20) also used SHED-CM as a therapy for a nerve lesion model causing dysphagia. They reported that SHED-CM protects the swallowing reflex, reduces pharyngeal residue and promotes axon regeneration.

In cases of diabetic polyneuropathy, Hata et al. (28) and Omi et al. (29) reports that using DPSC there is a significantly improvement of the motor and sensitive nerve conduction velocity, blood flow, myelin thickness and area of the nerve.

3. Eye tissue and skin

The therapeutic effects on damaged corneas was manifested by $4 \%$ of the articles included in this review, where Gomes et al. (14) performs the transplant of SHED to rabbit corneas with chemical damage, simulating a total deficiency of limbal stem cells. Clearer corneas were ob- 
tained in the groups with MSC transplantation compared to the control groups, where the transparency was greater and with less neovascularization in the group with medium degree damage, this group also showed multiple layers of corneal epithelium with well differentiated cells. Like the corneal injury, damage to the skin tissue was studied by $4 \%$ of the selected articles, which is equivalent to one article. Ueda y Nishino. (7) they carry out an investigation with 24 mice which expose them to UV-B rays and divide them into 3 treatment groups, where they are given a subcutaneous injection with: exfoliated temporary tooth stem cells, serum-free conditioned medium derived from stem cells of temporary teeth exfoliated and a control group. Both treatments performed with exfoliated temporary tooth stem cells reduced wrinkles in number, depth and area, being more effective in the treatment with exfoliated temporary teeth stem cells than the treatment with their serum free conditioned medium.

4. Liver tissue

$8 \%$ of the selected studies evaluated the therapeutic effects produced by SHED in mice with induced liver cirrhosis, where there is a coincidence in the results obtained in terms of a decrease in liver fibrosis, improvement of liver function and decrease in proinflammatory cytokines. Despite having used different methodologies, where Hirata et al. (6) performed intravenous administration of SHED-CM, while Yamaza et al. (5) performed a SHED direct transplant into the spleen of the mice.

5. Autoimmune diseases

$24 \%$ of the total studies included in this review (6 articles) used MSC from the oral cavity to be used as treatment in autoimmune diseases. Probably the immunomodulatory and immunosuppressive characteristics of MSCs as described above, makes them an attractive cell type for the treatment of autoimmune diseases.

\subsection{Rheumatoid Arthritis}

Rheumatoid arthritis is a disease that affects the joints of the body, which was studied by Ishikawa et al. (23) and Chen et al. (22) through the use of SHED-CM and MSC from the gingival tissue respectively, which were injected intravenously in mice. Both authors describe clinical improvement, decreased synovial inflammation, decreased expression of proinflammatory cytokines and a decrease in the destruction of bone and cartilage tissue. Ishikawa et al. (23) explained that the change in the polarity of macrophages, where the expression of genes related to proinflammatory macrophages (M1) that initiate inflammation and increases the expression of anti-inflammatory macrophages (M2) secreting anti-inflammatory cytokines counteracting M1 cells decreases. which the increase of M2 would favor the treatment of rheumatoid arthritis. While Chen et al. (22) explained it by the increase of regulatory $\mathrm{T}$ cells ( $\mathrm{T}$ lymphocytes), which when expressing FoxP3, CD39 and CD73 contribute to the suppression of the immune system.

\subsection{Autoimmune encephalomyelitis}

Three articles investigated the therapeutic effects of intraoral MSCs in autoimmune encephalomyelitis where they used mouse models with multiple sclerosis. Trubiani et al. (25) and Shimojima et al. (26)

perform intravenous administration with PLSCs or with SHED-CM while Rossato et al. (24) performs an intraperitoneal administration with SHED. In all three studies improvements in the clinical activity of the mice are manifested, however,

Shimojima et al. (26) and Trubiani et al. (25) they also describe a reduction in the demyelinization, in the axonal loss and in the number of infiltration of inflammatory cells, which was not mentioned in the research carried out by Rossato et al. (24) probably because he used a different route of administration than the other two authors.

The results of Rossato et al. (24) agree with the results of Chen et al. (22) described above, where they increase the T lymphocytes expressing FoxP3, which would allow the suppression of the immune system promoting the use of MSC as a treatment for diseases autoimmune 5.3 Miastenia gravis

The only study that used MSC of the dental follicle in autoimmune diseases, was an investigation carried out by Ulusoy et al. (27) for the treatment of mice to which myasthenia gravis was induced by immunization, this is a disease that produces weakness in the skeletal muscles. Within the results, there was a decrease in the severity of the disease, lower immunoglobulin levels, suppression of CD11b cells which stimulate phagocytosis, presentation of antigens and aggregation of neutrophils and as several authors have stated in this review, it decreases the production of proinflammatory cytokine $(5,6,8,22$ 24,26,27).

6.Tissue reperfusion

Several studies have investigated the therapeutic effects of mesenchymal stem cells on the reperfusion or ischemia of damaged tissues. This has been explained by the paracrine properties of these cells where they release growth factors that increase angiogenesis, decrease cellular apoptosis and can differentiate into damaged tissue cells. What could explain the results obtained by Tseng et al. (8) where by intravenously administering stem cells of temporary teeth exfoliated after heat stroke, there was a decrease in cellular apoptosis, of ischemic markers, hypoxia and brain damage were reduced. Likewise Zhang et al. (9) used DPSCs combined with brain-derived neurotrophic factor (BDNF) and observed an improvement at the neurological level in stroke cases that caused cerebral ischemia.

Within the limitations of the results found in this review is the comparison of studies that did not use the same methodologies in terms of the number of cells, the type of administration, the type of scaffolding and 
the number of passages of the cells used. Due to all the characteristics mentioned above, it is not possible to determine whether the use of MSCs from the oral cavity is a safe method at the extraoral level, without having a standardized protocol. In this review, all the studies found were conducted on animals, without finding studies in humans, so the results obtained are not possible to extrapolate completely to human health. According to the proposal made by Center for Evidence-Based Medicine (CEBM) of Oxford, these studies do not present a level of clinical evidence. Therefore, human studies are required to see the effectiveness of using stem cells from the oral cavity as treatment of diseases or injuries originating in extraoral tissues, however, it is necessary to standardize the protocols and carry out long-term studies before carrying out tests on human beings so as not to compromise their health.

In conclusion, the use of intraoral MSC presents potential therapeutic uses in other tissues of the organism, where at the bone tissue level there is a greater bone formation; at the level of nervous tissue improves motor activity, neuronal apoptosis decreases and nerve regeneration can occur; at the level of cutaneous tissue the folds decrease and at the level of liver tissue improves the structure and liver function. In relation to autoimmune diseases such as rheumatoid arthritis, autoimmune encephalomyelitis and myasthenia gravis, its potential therapeutic utility has been explained by the suppression of the immune system, where the infiltration of inflammatory cells decreases, the expression of proinflammatory cytokines and increases the expression of anti-inflammatory cytokines, which leads to a decrease in tissue destruction. Although the literature does not report adverse events after cell transplantation, the vast majority of articles included did not mention this information, in addition, the follow-up periods In the investigations, they did not exceed 3 months, so there is a lack of studies that evaluate long-term adverse events. In this review all articles included were made in animals, so it is necessary to highlight the lack of literature with a higher level of evidence. Therefore, it is necessary to conduct studies in humans to establish a final conclusion about the use of intraoral MSCs as a treatment in other tissues of the organism, however, a standardized and safe protocol for its use in humans is required.

\section{References}

1. Flores-Figueroa E, Montesinos JJ, Mayani H. Células troncales mesenquimales: Historia, biología y aplicación clínica. Rev Investig Clin. 2006;58:498-511.

2. Sanz AR, Carrión FS, Chaparro AP. Mesenchymal stem cells from the oral cavity and their potential value in tissue engineering. Periodontol 2000. 2015;67:251-67.

3. Egusa HWS, Nishimura M, Atsuta I, Kentaro Akiyama. Stem cells in dentistry - Part I : Stem cell sources. 2012;56:151-65.

4. Liu J, Yu F, Sun Y, Jiang B, Zhang W, Yang J, et al. Concise reviews: Characteristics and potential applications of human dental tissue-derived mesenchymal stem cells. Stem Cells. 2015;33:627-38.
5. Yamaza T, Alatas FS, Yuniartha R, Yamaza H, Fujiyoshi JK, Yanagi $\mathrm{Y}$, et al. In vivo hepatogenic capacity and therapeutic potential of stem cells from human exfoliated deciduous teeth in liver fibrosis in mice. Stem Cell Res Ther. 2015;6:171.

6. Hirata M, Ishigami M, Matsushita Y, Ito T, Hattori H, Hibi H, et al. Multifaceted Therapeutic Benefits of Factors Derived From Dental Pulp Stem Cells for Mouse Liver Fibrosis. Stem Cells Transl Med. 2016;5:1416-24.

7. Ueda M, Nishino Y. Cell-based cytokine therapy for skin rejuvenation. J Craniofac Surg. 2010;21:1861-6.

8. Tseng LS, Chen SH, Lin MT, Lin YC. Transplantation of human dental pulp-derived stem cells protects against heatstroke in mice. Cell Transplant. 2015;24:921-37.

9. Zhang X, Zhou Y, Li H, Wang R, Yang D, Li B, et al. Intravenous administration of DPSCs and BDNF improves neurological performance in rats with focal cerebral ischemia. Int J Mol Med. 2018;41:3185-94. 10. Petridis X, Diamanti E, Trigas GC, Kalyvas D, Kitraki E. Bone regeneration in critical-size calvarial defects using human dental pulp cells in an extracellular matrix-based scaffold. J Craniomaxillofac Surg. 2015;43:483-90.

11. Asutay F, Polat S, Gul M, Subasi C, Kahraman SA, Karaoz E. The effects of dental pulp stem cells on bone regeneration in rat calvarial defect model: micro-computed tomography and histomorphometric analysis. Arch Oral Biol. 2015;60:1729-35.

12. De Mendonca Costa A, Bueno DF, Martins MT, Kerkis I, Kerkis A, Fanganiello RD, et al. Reconstruction of large cranial defects in nonimmunosuppressed experimental design with human dental pulp stem cells. J Craniofac Surg. 2008;19:204-10.

13. Rezai-Rad M, Bova JF, Orooji M, Pepping J, Qureshi A, Del Piero F. Evaluation of bone regeneration potential of dental follicle stem cells for treatment of craniofacial defects. Cytotherapy. 2015;17:157281 .

14. Gomes JAP, Geraldes Monteiro B, Melo GB, Smith RL, Cavenaghi Pereira da Silva M, Lizier NF, et al. Corneal reconstruction with tissue-engineered cell sheets composed of human immature dental pulp stem cells. Invest Ophthalmol Vis Sci. 2010;51:1408-14.

15. Feitosa MLT, Sarmento CAP, Bocabello RZ, Beltrão-Braga PCB, Pignatari GC, Giglio RF, et al. Transplantation of human immature dental pulp stem cell in dogs with chronic spinal cord injury. Acta Cir Bras. 2017;32:540-9.

16. Nicola F do C, Marques MR, Odorcyk F, Arcego DM, Petenuzzo L, Aristimunha D, et al. Neuroprotector effect of stem cells from human exfoliated deciduous teeth transplanted after traumatic spinal cord injury involves inhibition of early neuronal apoptosis. Brain Res. 2017;1663:95-105

17. Asadi-Golshan R, Razban V, Mirzaei E, Rahmanian A, Khajeh S, Mostafavi-Pour Z, et al. Sensory and motor behavior evidences supporting the usefulness of conditioned medium from dental pulp-derived stem cells in spinal cord injury in rats. Asian Spine J. 2018;12:78593.

18. Nicola F, Marques MR, Odorcyk F, Petenuzzo L, Aristimunha D, Vizuete A, et al. Stem Cells from Human Exfoliated Deciduous Teeth Modulate Early Astrocyte Response after Spinal Cord Contusion. Mol Neurobiol. 2018;56:761-2.

19. Sugimura-Wakayama Y, Katagiri W, Osugi M, Kawai T, Ogata K, Sakaguchi K, et al. Peripheral Nerve Regeneration by Secretomes of Stem Cells from Human Exfoliated Deciduous Teeth. Stem Cells Dev. 2015;24:2687-99.

20. Tsuruta T, Sakai K, Watanabe J, Katagiri W, Hibi H. Dental pulp-derived stem cell conditioned medium to regenerate peripheral nerves in a novel animal model of dysphagia. PLoS One. 2018;13:117.

21. Mead B, Logan A, Berry M, Leadbeater W, Scheven BA. Intravitreally transplanted dental pulp stem cells promote neuroprotection and axon regeneration of retinal ganglion cells after optic nerve injury. Invest Ophthalmol Vis Sci. 2013;54:7544-56.

22. Chen M, Su W, Lin X, Guo Z, Wang J, Zhang Q, et al. Adoptive transfer of human gingiva-derived mesenchymal stem cells ameliorates collagen-induced arthritis via suppression of Th1 and Th17 cells 
and enhancement of regulatory T cell differentiation. Arthritis Rheum. 2013;65:1181-93.

23. Ishikawa J, Takahashi N, Matsumoto T, Yoshioka Y, Yamamoto N, Nishikawa M, et al. Factors secreted from dental pulp stem cells show multifaceted benefits for treating experimental rheumatoid arthritis. Bone. 2016;83:210-9.

24. Rossato C, Brandão WN, Castro SBR, de Almeida DC, Maranduba CMC, Camara NOS, et al. Stem cells from human-exfoliated deciduous teeth reduce tissue-infiltrating inflammatory cells improving clinical signs in experimental autoimmune encephalomyelitis. Biologicals. 2017;49:62-8

25. Trubiani O, Giacoppo S, Ballerini P, Diomede F, Piattelli A. Alternative source of stem cells derived from human periodontal ligament : a new treatment for experimental autoimmune encephalomyelitis. Stem Cell Res Ther. 2016;7:1-15.

26. Shimojima C, Takeuchi H, Jin S, Parajuli B, Hattori H, Suzumura A, et al. Conditioned Medium from the Stem Cells of Human Exfoliated Deciduous Teeth Ameliorates Experimental Autoimmune Encephalomyelitis. J Immunol. 2016;196:4164-71.

27. Ulusoy C, Zibandeh N, Yildırım S, Trakas N, Zisimopoulou P, Küçükerden $\mathrm{M}$, et al. Dental follicle mesenchymal stem cell administration ameliorates muscle weakness in MuSK-immunized mice. $\mathrm{J}$ Neuroinflammation. 2015;12:231.

28. Hata M, Omi M, Kobayashi Y, Nakamura N, Tosaki T, Miyabe M, et al. Transplantation of cultured dental pulp stem cells into the skeletal muscles ameliorated diabetic polyneuropathy: therapeutic plausibility of freshly isolated and cryopreserved dental pulp stem cells. Stem Cell Res Ther. 2015;6:162.

29. Omi M, Hata M, Nakamura N, Miyabe M, Ozawa S, Nukada H, et al. Transplantation of dental pulp stem cells improves long-Term diabetic polyneuropathy together with improvement of nerve morphometrical evaluation. Stem Cell Res Ther. 2017;8:1-11.

\section{Conflict of interest}

No conflicting interests. 